\title{
SNOTY OIL
}

From J. Dewey Soper, Chief Federal Misrtory Bird Officer for the Prairie Provinces, we have recuived a questionnaire with regard to the aundance of Snuwy Owls this winter. Periodically very heavy southern flights uf Snowy Owls (Alretic Owl, White Dwl) take place and such a flight has apprently occurred in eristern Canada this wintor. is for es our Christinas Bird Consuses indiceto thore has been ro unusual influx of thuse large owls in Snsketchowen this senson. However, Hr. Sopur is anxious to get exect information, so we will be grntuful if mombors will fill cut the following quistionnaire immodiately (aven if thuy havo alrendy sent in a consus) and roturn it to J. Duwey Soper, 536 Duminion Public Building, Jinnipog, Man.

SNOTY OTL OUESTIONITIIRT

$19+5-\quad 1946$

Plocse supply answors to tho folluwing quistions, basec on your observetions of the Snowy Owl curing the present periud. (Return by onrly February if possiblo)

Absent Plontiful

Serree Whon first noted.

Frirly common Whon most plontiful.

How men hove you soon during this poriod. Aing acitional coments.

How meny known to havo buin killed

Nive an addross of person supriying infurmation

Dit. of writing

Locality to which infumation applies 